\title{
Breaking Ships in the World-System: An Analysis of Two Ship Breaking Capitals, Alang- Sosiya, India and Chittagong, Bangladesh
}

\author{
R. Scott Frey \\ University of Tennessee, Knoxville \\ rfrey2@utk.edu
}

\begin{abstract}
Centrality in the world-system allows countries to externalize their hazards or environmental harms on others. Core countries, for instance, dump heavy metals and greenhouse gases into the global sinks, and some of the core's hazardous products, production processes and wastes are displaced to the (semi) peripheral zones of the world-system. Since few (semi) peripheral countries have the ability to assess and manage the risks associated with such hazards, the transfer of core hazards to the (semi) periphery has adverse environmental and socio-economic consequences for many of these countries and it has spawned conflict and resistance, as well as a variety of other responses. Most discussions of this risk globalization problem have failed to situate it firmly in the world-system frame emphasizing the process of ecological unequal exchange. Using secondary sources, I begin such a discussion by examining the specific problem of ship breaking (recycling core-based ocean going vessels for steel and other materials) at the yards in Alang-Sosiya, India and Chittagong, Bangladesh. Attention centers on the nature and scope of ship breaking in these two locations, major drivers operating in the world-system, adverse consequences, the unequal mix of costs and benefits, and the failure of existing political responses at the domestic and international levels to reduce adequately the adverse consequences of ship breaking.
\end{abstract}

Keywords: Ship Breaking, Hazardous Wastes, Environmental Injustice, Risk Globalization, World-Systems Theory, Ecological Unequal Exchange, Political Ecology, Capital Accumulation, Recycling

"... our world is an ocean world, and it is wild" (Langewiesche, 2004:8)

The world-system is a global economic system in which goods and services are produced for profit and the process of capital accumulation must be continuous if the system is to survive. ${ }^{1}$ The world-system can be conceptualized as a three-tiered open system (consisting of a core, semi-periphery, and periphery) that can be understood not only in "economic" terms but also in

\footnotetext{
${ }^{1}$ See especially Wallerstein $(1976-2011,2000,2004)$ for the origin and nature of the world-system perspective and Harvey (2010) for a recent discussion of continuous capital accumulation under capitalist relations in the global economy.
}

This work is licensed under a Creative Commons Attribution 4.0 United States License. Journal of World-Systems Research, Volume 21, Number 1, Pages 25- 49, ISSN 1076-156X 
"physical or metabolic" terms (a world-ecology according to Moore [2011b]): it is a system embedded in the natural environment and open to the entry of energy and materials and the exit of dissipated energy and material waste across regions of the system (Frey 1998a; Hornborg 2011; Martinez-Alier 2007, 2009; Moore 2011a, 2011b). In fact, the world-system and globalization itself can be described as a process of "ecological unequal exchange" (e.g., Clark and Foster 2009; Foster and Holleman 2014; Hornborg 2011; Jorgenson and Clark 2009a; Rice 2007,2009 ) or a process of "accumulation by extraction and contamination"-or the undervaluation of environmental and human health (Martinez-Alier 2002, 2009). Frey has described the process of ecological unequal exchange in terms of wealth and anti-wealth flows between core and (semi) periphery $(1998,2006 \mathrm{a}) .^{2}$

Wealth (in its many forms, including economic value, as well as material and energy) flows from the resource-rich countries of the (semi) periphery or "resource frontiers" to the core countries with adverse environmental and socio-economic consequences for the (semi) periphery (see, e.g., Bunker 1985, 2007; Bunker and Ciccantell 2005; Clark and Foster 2009b; Foster and Holleman 2014; Hornborg 2007; Moore 2007, 2010a, 2010b, 2011a; Robins 2011; Uglietti et al. $2015){ }^{3}$ On the other hand, the core displaces anti-wealth (wastes and the attendant risks, entropy broadly defined or appropriates carrying capacity or environmental space) ${ }^{4}$ by transporting it to the global sinks and to sinks or "waste frontiers" located in the peripheral zones of the worldsystem. Heavy metals, carbon dioxide and other greenhouse gases, as well as other hazardous materials such as lead and plastic are pumped into the global atmosphere and the oceans at high rates by the affluent or core countries of the world-system (see, e.g., Dietz and Rosa 1997; Jorgenson 2006; Kentor and Grimes 2006; Prew 2010; Roberts, Grimes, and Manale 2006; Roberts and Parks 2007; York, Rosa, and Dietz 2003; York and Rosa 2006).

Core-based transnational corporations export hazards to the peripheral zones of the world-system, including hazardous products (e.g., cigarettes, pesticides, and asbestos), production processes (dirty industries such as benzene and pesticide production plants and other production processes), and wastes (e-waste, lead batteries, and other wastes such as phenols, meracaptans, hydrogen sulfide) (see, e.g., Auyero and Swistun 2009; Clapp 2001; Clelland 2014; Dick and Jorgenson 2011; Frey 1995, 1998a, 1998b, 2006a, 2006b, 2012a, 2012b, 2013; Gottesfeld and Pokhrel 2011; Grineski et al. 2010; Hooks and Smith 2012; Margai and Barry 2011; Nixon 2011; Pellow 2007:73-224; Rice 2011). ${ }^{5}$ These export practices not only damage

\footnotetext{
${ }^{2}$ The world-system is best characterized as the unequal, asymmetrical flow of ecosystem goods and services as well as bads. Ecological unequal exchange is not confined solely to the core-periphery relations in the world-system but includes relations within nations and regions of the world-system.

${ }^{3}$ This is not only a current process (Bunker 1985; Bunker and Ciccantell 2005; Hornborg 2011), but a historical process that gave rise to the first core nations in Europe and modern global capitalism (Moore 2007, 2010a, 2010b; Robins 2011; Uglietti et al. 2015).

${ }^{4}$ One reviewer suggested that the use of the term entropy in the present context is misleading. But theories of ecological unequal exchange relations are based on the Second Law of Thermodynamics: the shift from order to disorder in the universe (see, e.g., Bunker 1985; Foster and Holleman 2014; Hornborg, 1998, 2009, 2011). Rifkin (1980:5) has noted: "According to the Entropy Law, whenever a semblance of order is created anywhere on earth or in the universe, it is done so at the expense of causing greater disorder in the surrounding environment." (See also Adams [1988].) Consider the fact that the core is able to increase its order (eliminating the environmental and human health risks embedded in obsolete hazardous ocean-going vessels) at the expense of the periphery which experiences increased disorder in the form of environmental and health risks when core-based ocean-going vessels are dismantled on its beaches.

${ }^{5}$ See Carmin and Agyeman (2011) and Faber's (2008, 2009) restatement of much of the earlier work by Frey (1998a, 1998b, 2006a) and others (Clapp 2001). Clelland (2014) uses the term "dark value" to describe part of the
} 
the environment, but they have adverse health, safety, and socio-economic consequences for the human populations of the (semi) periphery and they represent a form of environmental injustice (e.g., Bullard et al. 2005; Margai and Barry 2011). (Semi) peripheral countries are particularly vulnerable to the risks posed by hazardous exports because (semi) peripheral states and domestic firms have limited means for or interest in assessing and managing risks, and many workers and citizens are often unaware of the risks associated with these hazards.

This paper examines one core-based hazardous export to the periphery to illustrate a dimension of the process of ecological unequal exchange: the transfer of the core's ocean-going ships to yards located in Alang-Sosiya, India and Chittagong, Bangladesh for breaking. ${ }^{6}$ These two geographic sites-some would call them "toxic hotspots" or "sacrifice zones" to use Lerner's [2010] term - are the ship breaking capitals of the world, since a majority of the world's ships are broken on their beaches. Ship breaking is the process of dismantling and recycling or scrapping a ship for steel and other materials when it is no longer profitable for transport use due to age, as well as low shipping rates and/or high steel prices. The case of ship breaking documents one of the ways in which asymmetric, core-periphery relations are reproduced in the world-system. In other words, the process of ecological unequal exchange (as defined in terms of wealth and anti-wealth flows as noted above which serves the metabolic needs of core country economies) facilitates core capital accumulation within the current world-system through extraction from and contamination of the (semi) periphery. ${ }^{7}$

Discussion of this particular form of core-periphery reproduction or core capital accumulation proceeds in five steps. The nature and scope of ship breaking are first examined and the specific political-economic forces driving the transfer of ships to the (semi) periphery for breaking are outlined. The extent to which ship breaking contributes to adverse health, safety, environmental, and socioeconomic consequences in the periphery is then examined. An approximate analys is of the costs and benefits is presented in an effort to assess the neo-liberal claim that the movement of ship breaking and other hazards to the (semi) periphery is beneficial to the core and the states, domestic firms, workers, and citizens of these two peripheral countries. Various policy and political responses to curb the adverse consequences of ship breaking are briefly reviewed and discussed. It is argued that conventional efforts (whether "globalization of regulation" or "renationalization of capital") and the emergence of transnational NGO networks (sometimes referred to as "globalization from below" [Brecher, Costello and Smith 2000; Chase-Dunn 2002, 2010; Subramaniam 2015]) to deal with ship breaking and many other hazardous exports have had limited success because they fail to fully take into account the existence of a world-system based on ecological unequal relations between core and periphery. The paper concludes with

value created through the core's extraction of wealth in its many forms from the (semi) periphery and its ability to offshore or externalize what I call anti-wealth. See Urry (2014) for a discussion of the offshoring of not only antiwealth but economic and other forms of wealth.

${ }^{6}$ See the documentary film Echoes of Shipbreaking (2014), produced by Vega Productions and directed by Prathamesh Rane at https://www.youtube.com/watch?v=vV3M4jqD-Sg. Shortly before completing an earlier draft of this paper, I discovered Demaria's (2010) insightful paper on ship breaking in the yards of Alang-Sosyia, India. Although we take different approaches and he confines his attention to India, I have incorporated several important elements from Demaria's paper that are noted in the text.

${ }^{7}$ See Foster and Holleman (2014), Hornborg (1998, 2009, 2011), Jorgenson and Clark (2009), and Rice (2007, 2009) for detailed discussions of the process of ecological unequal exchange in which the core extracts energy and material from the (semi) periphery and exports entropy to the (semi) periphery. Harvey (2010) provides a recent discussion of capital accumulation, which is relevant for world-systems theory and the processes of ecological unequal exchange. 
several suggestions for future research on the hazardous waste stream in the world-system and ongoing conflicts and efforts to curb it.

\section{The Nature and Scope of Ship Breaking in Bangladesh and India}

The global shipping industry, which facilitates the transport of wealth to the core and anti-wealth to the periphery, is one of the major components of the infrastructure underlying the worldsystem's social metabolism (Demaria 2010; Bunker and Ciccantell 2005). ${ }^{8}$ Consider, for instance, the fact that a majority of the global trade in materials and goods is by sea: $80 \%$ of all raw materials and manufactured goods. Slightly more than 100,000 ocean-going vessels were operating during the 2009-2010 period (see Demaria 2010; International Maritime Industry 2011:8; World Bank 2010).

After an average life span of 25 to 30 years or longer, many ocean-going vessels are scrapped for their steel and other resources, though the number of vessels sent to the breaking yards varies according to freight charges and steel prices (Demaria 2010; Greenpeace International 2000, 2001; World Bank 2010). The industry is subject to boom and bust cycles. It thrives during times of economic contraction and declines during periods of economic growth. Approximately 1,000 (more than 25 million tons) of the 100,000 ocean-going vessels-including oil tankers, container ships, bulk carriers, naval ships, chemical tankers, and general cargo ships-were sent to the periphery in 2009 for scrapping (Puthucherril 2010:12-14; Robindebois.org 2010; World Bank 2010:3; see also Greenpeace International [2000] for earlier figures). The number of ships broken increased dramatically during the economic downturn in 2008-2009 when there was excess shipping capacity (Robindebois.org 2009). And it is expected that there will be a dramatic increase in the number of ships broken in the near future as a result of the International Maritime Organization's regulation phasing out older, single-hull tankers during the period from 2010 to 2015 (Karim 2010; Puthucherril 2010:14; World Bank 2010). Other options for obsolete ships or ships of limited economic value include moth-balling or scuttling, but these options are problematic: moth-balling does not solve the long-term problem of disposal, and sinking a ship leads to toxic discharges and forgoes the recyclable value of the ship (Puthucherril 2010:14)

Over 90 percent of the vessels slated for breaking - typically owned by interests based in the core but sailing under foreign flags of convenience-are currently transported to Bangladesh, Pakistan, China, the Philippines, Turkey, and Vietnam. ${ }^{9}$ The remaining ships are broken in

\footnotetext{
${ }^{8}$ Bunker and Ciccantell (2005: xxii) describe the role played by the shipping industry in the emergence of the worldsystem in the following way: “... the development of shipping technology was a critical, and very concrete, element in the material intensification and spatial expansion of the world economy over the past six hundred years, proving that the nation that could develop and control the most efficient shipping could also guarantee its access to cheap raw materials." The global shipping industry has grown dramatically since the 1960 s. This growth is in large part a result of the development of standardized shipping containers (see Cudahy, 2006; Levinson, 2006). These containers have facilitated efficient production and transport of manufactured goods in the world-system. Individual container ships carry thousands of tons of freight (mostly from East Asia) and travel more than two hundred thousand miles each year. See American Association of Port Authorities (2008) for data on total cargo volume and container traffic at many ports in the world-system. Halpern et al. (2008) present estimates of the environmental impact of the shipping industry and other human activities on marine ecosystems around the world. And Shin and Ciccantell (2009) provide an excellent overview of the changing nature and location of shipbuilding in the world-system.

${ }^{9}$ Ocean-going vessels change their nation of registry to reduce national and regional regulations (Kotoky 2015). The British Petroleum's (BP) Deepwater Horizon, for instance, was registered under the flag of the Marshall Islands in
} 
locations such as the United Kingdom and the United States under strict health, safety, and environmental regulation. Ship breaking is pursued mainly in the former countries because labor is cheap; health, safety, and environmental regulations are weak; workers are desperate for jobs; and the recovered steel in used in domestic construction activities. The ship breaking industry was centered in the United States, Japan, and the United Kingdom during and after World War II, but it moved to Turkey and Spain in the $1960 \mathrm{~s}$, then to Korea and Taiwan in the $1970 \mathrm{~s}$, and it shifted to several countries in South and Southeast Asia starting in the mid-1980s (Demaria 2010; World Bank 2010). In other words, ship breaking moved from the core to peripheral countries in Asia when the cost of breaking ships in the core (due to increased regulations and other forms of "ecological modernization," as well as increased labor costs estimated to be more than 50 times that of developing countries [Rousmaniere and Raj 2007:362]) exceeded the price obtained from the scrapped metal. ${ }^{10}$

Ship breaking can be defined as a "pollution haven" industry since it has moved from several core countries to Bangladesh, India, Pakistan, and several (semi) peripheral countries due to increased environmental, health, and safety regulations in the core, as well as low wage labor available elsewhere. ${ }^{11}$ But other factors have clearly contributed to the movement of the ship breaking industry to South and Southeast Asia (see, e.g., Buerk 2006; Demaria 2010; Hossain and Islam 2006:2). These include strong domestic markets for steel and other materials; the temperate climate of the region allows ship breaking to take place throughout the year; high tides and favorable beach conditions; and close proximity to the main eastbound sea trade routes.

Sixty to seventy percent of the ships scrapped each year go to the Alang-Sosiya yards in India (often described as the ship breaking capital of the world-system) and Chittagong, Bangladesh (Greenpeace International and International Federation for Human Rights 2005; Robindebois.org 2009, 2010, 2011; World Bank 2010:14), though China has become increasingly important in breaking ships and may become more important in the future (See

an effort to reduce US government regulations (Freudenburg and Gramling 2011). This factor was undoubtedly partly responsible for the BP oil spill disaster.

${ }^{10}$ Ecological modernization theorists (e.g., Mol 2001) maintain that highly developed countries are adept at dealing with their environmental problems because of increased public concern with the environment, the economic means, and increased environmental regulation. One of the ironies (or, perhaps hypocrisies) surrounding the ecological modernization perspective is that the highly developed countries do often deal with their environmental harms effectively, but they do so by displacing them to countries located in the peripheral zones of the world-system. Of course, the movement of ship breaking to the periphery (and the movement of other hazards from the core to the periphery, see Bonds and Downey [2012]) can be framed as a manifestation of ecological modernization processes. Ehrlich and Holdren (1971) developed the term the "Netherlands Fallacy" to refer to the fallacy of thinking that the environmental impacts of rich countries are contained within their national boundaries. And it is this fallacy that is entrenched in the ecological modernization narrative. See York and Rosa [2003] and Bonds and Downey (2012) for theoretical and empirical critiques of the ecological modernization perspective.

${ }^{11}$ A research literature has emerged around the "pollution haven" debate or the idea that the core's hazardous industries and wastes move to the (semi) periphery to escape environmental regulation (see Bonds and Downey 2012; Commission for Environmental Cooperation 2012; Frey 1998b, 2006a, 2012a; Levinson and Taylor 2008; Muradian and Giljum 2007). See Clapp (2002) for an early but nonetheless relevant critical review of the literature, much of the research was conducted by neo-liberal economists reporting little or limited support for the thesis. Clapp (2002:11-13) is highly critical of this research and notes that the hazardous waste management industry (this would include industries like ship breaking, battery recycling, e-waste recycling, among others) has not been the subject of research by neo-liberal economists. See recent research on several of these industries, which supports the "pollution haven" thesis (Frey 2012a; Committee for Environmental Cooperation 2012). On the other hand, subsequent research conducted by economists on the thesis is open to Clapp's criticisms (e.g., Cole 2004; Eskeland and Harrison 2003; Levinson and Taylor 2008). 
Figure 1 for the geographic location of the two ship breaking capitals). Leadership in ship breaking has alternated between India and Bangladesh over the last ten years (World Bank 2010:14).

\section{Figure 1. Location of Alang, India and Chittagong, Bangladesh}

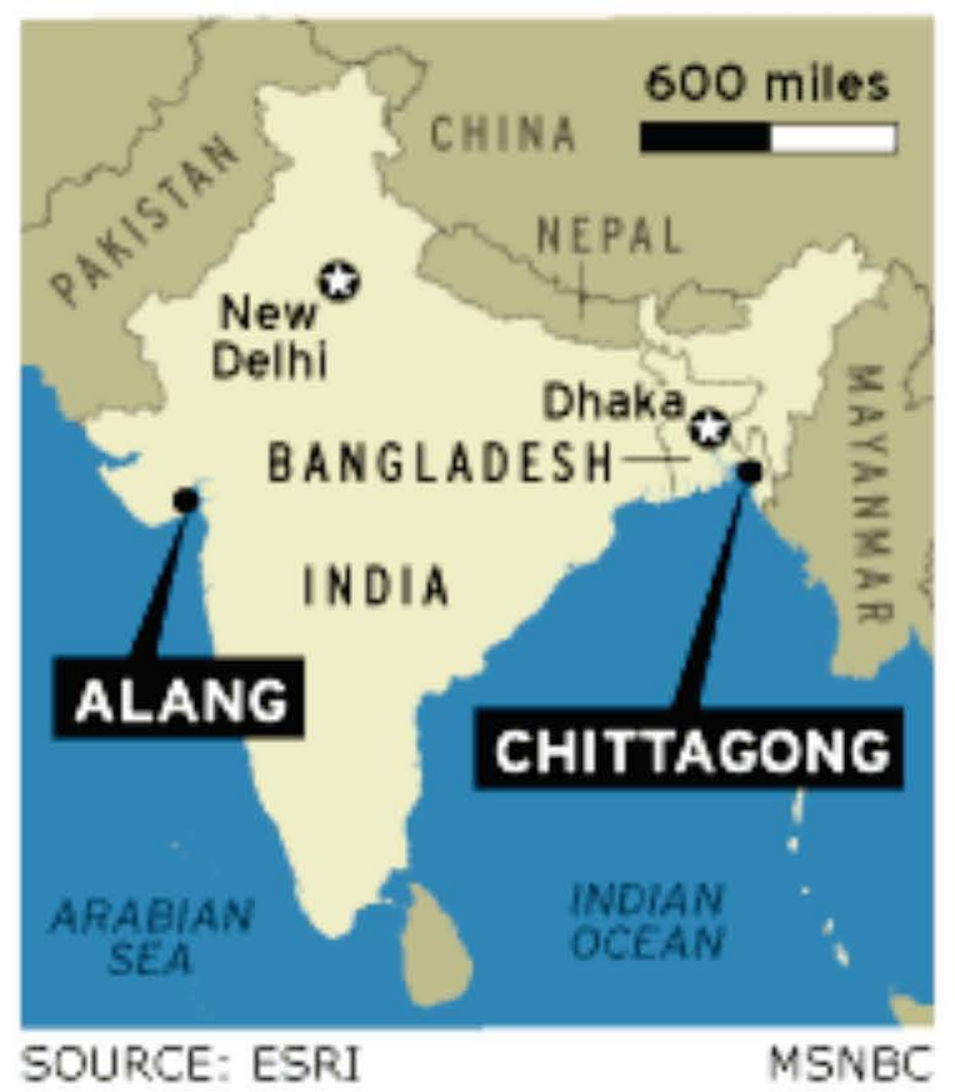

\section{Steps in Breaking a Ship}

Brokers based in Dubai, Hamburg, London (where Clarkson, the world's largest ship broker is based), and Singapore sell the core's ships (typically registered under flags of convenience) to breakers who pay anywhere from 400 to 500 dollars or more per ton for the ships (Robindebois.org 2010). The buyers have a financial incentive to break ships quickly so they can recover their investments. It normally takes a workforce of 200 to 250 workers three to five months to dismantle an average-sized ship (Demaria 2010).

Several steps are followed in this extremely dangerous process once the ship is anchored offshore (see, e.g., Buerk 2006; Demaria 2010; Langewiesche 2004; Puthucherril 2011:285-286; Rousmaniere and Raj 2007; World Bank 2010). Local authorities must first complete various legal formalities (ensuring, for example, the ship is gas free to reduce the risk of explosions). The ship is then beached at full speed during high tide. Once the ship is beached, workers vent 
flammable gases in the interior of the ship by hammering or punching large holes in the hull and seawater during high tide washes out the fuel tanks. Ships are stripped of all furnishings and appliances, as well as other material - such as asbestos, generators, wiring, life boats, life vests, pipes, toilets, wash basins, navigation equipment, wooden doors, foam, and the like-and often sold along the road outside the yards. Large sections of the ship are then cut off by gas torches and dragged closer to shore by giant winches. The large sections of steel are cut into smaller pieces and teams of men carry the metal sections to trucks for loading and removal. The steel is transported by truck to re-rolling mills for recycling. The recycled steel, often in the form of reinforcement rods, is used domestically in building and road construction.

Thousands of mostly young, male, and illiterate migrant workers from poor rural areas are employed in the ship breaking yards. ${ }^{12}$ Workers are categorized into several groups: those using torches to cut up ships and their helpers, those carrying large iron plates, laborers, contractors, supervisors, winch operators, crane drivers, fitters, carpenters, asbestos workers, and firemen. Daily wages are anywhere from $\$ 2$ to $\$ 7$ per day, depending on the job (DeMaria 2010; Puthucherril 2011:287).

The Case of the Alang-Sosiya Yards in India. Alang is located in the highly prosperous, manufacturing state of Gujarat and the shipyards are located on a six-mile stretch of beach on the western coast of the Gulf of Cambay. Ship breaking employed over 40,000 workers and others in related industries in early 2000 and upwards of 50,000 by 2009 (Demaria 2010; Greenpeace International 2000, 2001; International Federation for Human Rights 2002). Established in 1982, the Alang-Sosiya yard is the largest breaking yard in the world in terms of the actual number of ships broken. Alang-Sosiya was the number one ship breaking site in 2007 (with 129 ships), 2008 (194), 2009 (435), and 2010 (422) (see Robindesbois.org 2008, 2009, 2010, 2011). An average of approximately 200 ships have been dismantled each year for the past decade (Robindebois.org 2010). Over 5,000 ships have been dismantled since the yard opened (Demaria 2010:255). In addition to the recycling of steel and other metals, hazardous wastes are generated as noted above (Basha et al. 2007; Demaria 2010; Greenpeace International 2001; Reddy et al. 2005).

The Case of Chittagong, Bangladesh. Chittagong is the primary port of Bangladesh and the center of much of the country's industry (Rousmaniere and Raj 2007; World Bank 2010). The Chittagong yards are located on a ten-mile stretch of beach named Fauzdarhat, which is approximately twelve miles northwest of Chittagong and located on the Bay of Bengal. Ship breaking was introduced in 1969 when a vessel (the Greek ship M.D. Alpine) was beached on the shore during a storm (Puthucherril 2010:27). Large ships (tankers, cargo ships, and container ships) have traditionally been dismantled at the yards. The yards have employed upwards of 20,000 to 22,000 workers and 200,000 people are thought to be employed in businesses related to ship breaking such as shops and steel re-rolling mills, and the dependents of workers may number as many as 500,000 people (Buerk 2006; Hossain and Islam 2006; Puthcherril 2010:28; World Bank 2010). The Bangladesh Ship Breakers Association and government officials maintain that Chittagong surpassed Alang in terms of steel tons broken in late 2008 (Anonymous

\footnotetext{
${ }^{12}$ The International Federation for Human Rights and Young Power in Social Action (2008:7) report that 25\% of the workers in Chittagong are under the age of 18 , some as young as 12 . They identify the main cause of child labor to be poverty and debt, resulting from a family's loss of land, disappearance of a father, the cost of a wedding, or some combination of the three.
} 


\section{Journal of World-Systems Research}

2008; Basha et al. 2007), but the Bangladeshi Supreme Court put heavy restrictions on importing ships for breaking in early 2010 that reduced the number of ships broken in 2010 and 2011 (Robindebois.org 2010; 2011). The numbers of ships dismantled each year from 2007 to 2010 were 105, 182, 214, and 93, respectively (Robindebois.org 2008, 2009, 2010, 2011). The future of ship breaking remains somewhat uncertain in Chittagong, though recent developments suggest that ship breaking will return to its previous level (Anonymous 2011). Hazardous materials and unsafe dismantling practices are pervasive in the yards (Basha et al. 2007; Greenpeace International and International Federation for Human Rights 2005; International Federation for Human Rights and Young Power in Social Action 2008; Rousmaniere and Raj 2007; World Bank 2010).

\section{Adverse Consequences}

Approximately 95 percent of an ocean-going vessel's bulk consists of steel (much of which can be recycled) and the remaining 5\% consists of hazardous materials (Greenpeace International 2000; World Bank 2010). Hazardous materials include bacterial oil sludge, toxic paints, asbestos, halons in foam and firefighting equipment (ozone depleting substances), fuel residues, heavy metals (arsenic, cadmium, chromium, lead, mercury), organotins or biocides, persistent organic pollutants (dioxins, PVCs, PAHs), and radioactive substances (Basha et al. 2007; Buerk 2006; Demaria 2010; Greenpeace International and International Federation for Human Rights 2005; Hossain and Islam 2006; Puthucherril 2010:18-19; Reddy et al. 2005; Tewari et al. 2001). Such hazards can damage the environment and adversely affect human health through occupational exposure and environmental dispersion in the soil, water, and air or large-scale failures such as explosions and fires. Workers come into direct contact with toxic materials on the job and in their squalid sleeping quarters located in the yards (Basha et al. 2007; Greenpeace International 2001; Greenpeace International and International Federation for Human Rights 2005; Hossain and Islam 2000; Reddy et al. 2005; Sahu 2014; World Bank 2010). Numerous undesirable social and economic consequences are also associated with ship breaking, including staggering economic costs and an inequitable distribution of costs and benefits to be discussed below (World Bank 2010).

Bangladesh and India are particularly vulnerable to the risks posed by ship breaking because of the young, poorly trained, uninformed, undernourished, unhealthy, migrant workforce with limited access to safety and protective equipment, adequate housing and sanitation facilities, and limited risk assessment and management skills (e.g., Demaria 2010; Greenpeace International and International Federation for Human Rights 2005; Hossain and Islam 2006; International Federation for Human Rights 2002; Sahu 2014). The heavy humidity and heat in the local environment discourages the use of protective clothing and gear even when it is available. Most of the work is done by hand with hammers, torches, and crowbars (Puthucherril 2011:286).

Other problems exist, including limited awareness of the risks associated with hazards, nonexistent labor unions, politically unresponsive state agencies, inadequate risk assessment and management capabilities, and limited health care facilities (Sahu 2014). In addition, organized activism among workers is limited because potential participants are unaware of their rights and have little time for such activity since they work six days a week and there are few channels through the courts or legislature for effective public participation. The problem is compounded 
by labor conditions: workdays often run from 7:00 a.m. to 7:00 p.m. with no overtime or leave benefits, and wages are anywhere from $\$ 2.00$ to $\$ 7.00$ (or less) per day depending on the specific job and location (Demaria 2010; International Federation for Human Rights 2002; Greenpeace International and International Federation for Human Rights 2005; Hossain and Islam 2006; Sahu 2014; World Bank 2010).

\section{Environmental Risks}

Emissions of toxic substances contained in the bilge and ballast waters of ships and the improper disposal of hazardous wastes and materials contribute to the risk of environmental damage. Environmental damage includes soil contamination, soil erosion, water pollution, contamination of coastal regions and subsequent biodiversity loss such as the destruction of vast areas of mangroves, air pollution, and threats to plant and animal health. Since reliable data do not exist on the full scope and nature of the problem in the shipyards of Alang-Sosiya and Chittagong, it is not possible to estimate the actual environmental damage (see, e.g., Basha et al. 2007; Demaria 2010:256; Greenpeace 2001; Hossain and Islam 2006:18-32; Puthucherril 2011:288; Reddy et al. 2005; World Bank 2010:33-37). Such damage is a serious problem because it can deplete important natural resources, disrupt the stability of larger ecosystems, and threaten human health and the livelihoods of farmers and fishers in surrounding villages (Demaria 2010). And, of course, hazardous materials are carried outside the yards by equipment and other materials taken off the ships and reused elsewhere. Steel re-rolling mills, for example, disperse toxic materials into the atmosphere through heating steel coated with toxic materials. Rising sea levels resulting from climate change may increase environmental damage by washing out "legacy pollution" on the beaches of the breaking yards (World Bank 2010:38-39).

\section{Human Health and Safety Risks}

Occupational and environmental exposure to the hazards posed by ship breaking and the attendant health consequences are not fully known, but those exposed are at a high risk of death, disease, and injury because of their increased susceptibility to various site-specific cancers, skin irritation, respiratory problems such as asbestosis, and neurobehavioral problems. Accidents are common and workers are at increased risk of death and injury from snapping cables, chemical spills, welding fumes, falls, falling objects, fires, and explosions (Demaria 2010; Greenpeace International and International Federation for Human Rights 2005; Hossain and Islam 2006; Puthucherril 2011:285-288; Rousmaniere and Raj 2007; Sahu 2014; World Bank 2010).

Since reliable data do not exist on the full occupational and environmental exposure to the emissions of hazardous substances in the yards, it is not possible to estimate the actual number of deaths or cases of disease and injury that can be attributed to them. It is quite clear, given what we know about the environmental risks discussed above, that health problems linked to ship breaking are pervasive. Air pollution and water contamination have been well documented (Basha et al. 2007; Reddy et al. 2005). Hazardous waste management is also a problem, for hazardous wastes are dumped in a haphazard fashion (Demaria 2010; Puthucherril 2010, 2011). Accidents and the adverse health and safety conditions facing workers and the inhabitants of the areas surrounding the yards are serious (Greenpeace International and International Federation for Human Rights 2005; International Federation for Human Rights and Young Power in Social Action 2008; Sahu 2014; World Bank 2010). 


\section{Journal of World-Systems Research}

Adverse human health effects have been reported by a number of researchers (Greenpeace International 2001; Greenpeace International and International Federation for Human Rights 2005; Sahu 2014; World Bank 2010). The conditions are so severe that "... a doctor at the Red Cross Hospital in Alang [is reported to have said that] working one day in the ship breaking yards is equal to smoking 10-15 packs of cigarettes" (Greenpeace International and International Federation for Human Rights 2005:10). Reliable data on the number of accidental deaths and future deaths resulting from diseases with long latency periods such as asbestosis, lung cancer, and mesothelioma are not available, but a recent study of Taiwanese ship breaker workers who had stopped working for a period of 24 years indicated they are at substantially increased risk of asbestos-related diseases such as overall cancer, oral cancer, lung cancer, and mesothelioma (Wu et al. 2014). Nixon (2011) captures this idea of long-term consequences with his concept of "slow violence." Estimates indicate that one in every six workers may have asbestosis and workers are at inflated risk of lung and related forms of cancer in the shipyards of Alang-Sosiya and Chittagong (Greenpeace International and International Federation for Human Rights 2005). Greenpeace International and International Federation for Human Rights (2005) estimate that thousands of workers have died in the last several decades and thousands are at risk in the future.

Communicable diseases are also a problem in the yards. One researcher described the situation in Alang in the following way:

The labourers in Alang live in poor housing and sanitary conditions and little attention is paid to their health and safety concerns. According to the physicians in and around Alang who treat numerous Alang patients, the combination of hazardous working conditions, congested and unhygienic living conditions, poor drinking water, (...) and rampant prostitution have given rise to a number of skin, gastrointestinal, and liver diseases besides tuberculosis, leprosy, malaria, malnutrition, cancer, HIV/AIDS, and other sexually transmitted diseases (cited in Greenpeace International and International Federation for Human Rights 2005:11).

The stories of a number of workers who were injured or killed in the breaking yards of Alang-Sosiya and Chittagong are included in a 2005 report by Greenpeace International and the International Federation for Human Rights (2005). Several of these "witness stories" from Alang and Chittagong are quoted at length to illustrate the seriousness of the problem:

Alang-Sosiya, India

Bhaskar Zena was 35 when he was burnt alive at plot no. 17. His family in Nuashai did not get any compensation (Greenpeace International and International Federation for Human Rights 2005:37).

My name is Ramhari. I am 53 years old and I have lived in Dudurapada hamlet of Adapada village all of my life, except for the four black months in Alang. There are about 3,000 households in my village and about 1,000 young people have migrated to Alang looking for a job. Out of sheer poverty I also left for Alang looking for a job. I was desperate after one of my sons died of a snakebite. 
I stayed in Alang for a few months, not aware of what could happen to me. One morning a major catastrophe struck me and my family. I was working on the deck of a ship beached at plot no. 49. Somebody dropped a large iron ball, which struck my head. I fell unconscious and was brought to the hospital, but I did not know how long I stayed there. Maybe two or three months. I wasn't aware of my condition, but gradually I found out that my left arm was fully paralysed.

I encountered a great hardship with my family and was compelled to start begging. Our lives have become extremely miserable. Since the accident I have lost six children due to various illnesses. I tried my best to obtain some kind of treatment for them, but it didn't work as I didn't have enough money. I undertook several things, basically washing dishes in small hotels, to feed my family.

My wife couldn't bear all this and she has since become mentally ill. How could one bear so much loss? I don't remember everything clearly, because I was grief stricken. My mind was in one place and my body somewhere else.

After the incident, they paid me 3,000 rupees ( 60 euros) plus some money for medical treatment. I knew that the money given to me was meager, but I couldn't do anything. How can I fight in an alien place where I know nothing and nobody? The money didn't last long. Now I am forced to beg, due to the ship breaking work (Greenpeace International and International Federation for Human Rights 2005:30).

Chittagong, Bangladesh

Shorab died in July 1998 while he was lifting an oxygen bottle, used for gas cutting, onto a ship. The rope broke and the bottle fell on his chest. He fell in the muddy water. Two hours later his fellow workers found his body (Greenpeace International and International Federation for Human Rights 2005:21).

[Muhun a]... 36-year old cutter from Sylhet was injured during the major explosion on the TT Dina oil tanker on 31 May 2000 in Chittagong. This explosion killed 16 workers and left 40 people injured. Muhun escaped death on that occasion, but three years later he suffered another blast that left him paralysed (Greenpeace International and International Federation for Human Rights 2005:29).

\section{Economic Costs}

The economic costs associated with the cleanup of contaminated sites in Alang and Chittagong, as well as the surrounding communities and beyond are high. The treatment and compensation of the victims of hazardous exposures are potentially very costly. Destruction of marine life and the livelihoods of fishers, mangroves, biodiversity, soil and the livelihods of farmers, water and air quality, and other natural resources is also likely to be costly. Reductions in human health are costly, and they can impede future economic growth (Price-Smith 2001). These and other 


\section{Journal of World-Systems Research}

tangible and intangible economic costs associated with the transfer of this particular hazardous industry appear to be substantial (Demaria 2010; Rousmaniere and Raj 2007; World Bank 2010).

\section{Social Costs and Environmental Injustice}

Proponents and the institutions of global environmental goverance (GEG) and proponents of ecological modernization maintain that international trade spreads benefits such as the reduction of environmental harms and provides many benefits and opportunities for countries engaged in recycling practices such as ship breaking (see, e.g., the discussion of Okereke [2008] on environmental justice and neoliberal environmental goverance). Contrary to the goals of GEG, most of the costs or risks associated with the transfer of ship breaking to the beaches of Bangladesh and India (and other hazards for that matter) are distributed in an unequal fashion. ${ }^{13}$ In other words, most of the benefits go to the core-based interests that control shipping and the brokers and breakers/owners who profit from the sale of the ships, while Bangladesh and India bear most of the costs. Losses are distributed in an unequal fashion within Bangladesh and India: some groups - especially the state and local capital - are able to capture the benefits and other groups - those marginalized by age, class, race/ethnicity, and geographic location, including workers and their families as well as those in surrounding communities-bear the costs (Greenpeace International and International Federation for Human Rights 2005; International Federation for Human Rights and Young Power in Social Action 2008; Sahu 2014; World Bank 2010).

\section{An Approximate Analysis of Economic Costs and Benefits}

Are the costs associated with the displacement of ship breaking to countries like Bangladesh and India offset by the economic and other benefits as proponents of neoliberalism (Grossman and Krueger 1993, 1995) and some ecological modernization theorists (Mol 2001) suggest? After all, ship breaking employs thousands of poor workers desperate for jobs in Bangladesh, India, and elsewhere. The steel recovered from the ships is recycled and used domestically in road and building construction which reduces the environmental and health impacts of mining and reduces energy use; the yards supply upwards of $80 \%$ of Bangladesh's steel and upwards of $15 \%$ of India's steel at half the price of furnace produced steel (Demaria 2010; International Federation for Human Rights 2002; Hossain and Islam 2006; Rousmaniere and Raj 2007; World Bank 2010). In addition, import duties and other fees on incoming ships provide revenue for the state.

Answering the question raised above as noted by some analysts (Frey 2006a, 2012a) is problematic because it is difficult to identify, estimate, and value the costs and benefits (especially the costs) associated with hazards in monetary terms (see, e.g., Frey, McCormick, and Rosa 2007; Funtowicz and Ravetz 1994). Despite suggestions and efforts to the contrary (e.g., Logan 1991), there is no widely accepted factual or methodological basis for identifying, estimating, and valuing the costs and benefits associated with the flow of core hazards to the

\footnotetext{
${ }^{13}$ The unequal distribution of the costs or risks between core and periphery and within the periphery is contrary to Ulrich Beck's $(1992,1999)$ "risk-society" thesis. His argues that risks increasingly impact both the poor and rich. See Alario and Freudenburg (2010) who use the analogy of the Titanic sinking in their discussion of the unequal distribution of risks in the "risk-society."
} 
periphery. Even if the consequences of hazardous exports could be meaningfully identified and estimated, there remains the question of valuing them in monetary terms and identifying appropriate discount rates and time horizons. Economists typically look to the marketplace for such a valuation, but adverse health, safety, environmental, and socio-economic consequences are not traded in the marketplace. Efforts have been made to deal with this problem by using either expert judgment or public preferences (Mitchell and Carson 1989), but such techniques are deeply flawed and morally suspect (see Dietz, Frey, and Rosa 2002; Foster 2002a).

Comments contained in the often cited 1991 memo by former World Bank Chief Economist Lawrence Summers (1992) are worth quoting at length because they illustrate the difficulties and contradictory outcomes of applying traditional economic reasoning to the transfer of hazardous industries and wastes like ship breaking to the periphery. Sounding a bit like Marie Antoinette, Summers notes:

Just between you and me, shouldn't the World Bank be encouraging more migration of the dirty industries to the LDCs? I can think of three reasons:

(1) The measurement of the costs of health-impairing pollution depends on the forgone earnings from increased morbidity and mortality. From this point of view a given amount of health-impairing pollution should be done in the country with the lowest cost, which will be the country with the lowest wages.

(2) The costs of pollution are likely to be non-linear as the initial increments of pollution probably have been very low cost. I've always thought that underpopulated countries in Africa are vastly under-polluted; their air quality is probably vastly inefficiently low compared to Los Angeles or Mexico City....

(3) The demand for a clean environment for aesthetic and health reasons is likely to have very high income-elasticity. The concern over an agent that causes a onein-a-million chance in the odds of prostate cancer is obviously going to be much higher in a country where people survive to get prostate cancer than in a country where under-5 mortality is 200 per thousand. Also, much of the concern over industrial atmosphere discharge is about visibility of particulates. These discharges may have little direct health impact. Clearly trade in goods that embody aesthetic pollution concerns could be welfare enhancing. While production is mobile the consumption of pretty air is a non-tradable.

The editors of The Economist (2007:14) magazine based in London made a similar argument more recently:

...the best way of recycling waste may well be to sell it, often to emerging markets. That is controversial, because of the suspicion that waste will be dumped, or that workers and the environment will be poorly protected. Yet recycling has economics of scale and the transport can be virtually free--filling up the containers that came to the West full of clothes and electronics and would otherwise return empty to China. What's more, those who are prepared to buy waste are likely to make good use of it.

Such reasoning undervalues nature and assumes that human life in the periphery is worth much less than in the core because of wage differentials (see also Foster 2002b; Frey 2006a; 


\section{Journal of World-Systems Research}

Harvey 1996:368; Martinez-Alier 2009). Although most costs occur in the periphery, and many of the benefits are captured by core countries and elites located in the periphery, the costs to the periphery are deemed acceptable because life is defined as worth so little. ${ }^{14}$ In sum, it can be argued that the "costs" - once we consider non-economic values and long-term time horizons, including impacts on the environment, human and animal health, and the unequal distribution of the health, safety and environmental risks - outweigh the benefits, but the valuation discourse of economics of the neo-liberal variety continues to dominate the policy discourse and empowers those who benefit from the industry, impeding efforts to effectively regulate the industry.

\section{What Can Be Done? And Who Should Do it?}

The image of ghost ships sailing to the breaking yards located on the beaches of India and Bangladesh is a disturbing one. Unlike the Flying Dutchman, however, many of these ships have been and will be beached and broken with adverse health, safety, environmental, and socioeconomic consequences. The displacement of ship breaking to the beaches of Bangladesh and India can be framed as racist (Bullard et al. 2005; Pellow 2007:37ff; Puthucherril 2010:51), but it represents something more. It reflects the unequal power relations underlying relations between countries occupying different positions in the world-system. Centrality in the world-system allows core countries to engage in Not-In-My-Backyard (NIMBY) like behavior and to impose their anti-wealth on the (semi) periphery.

Efforts to curb the adverse consequences associated with ship breaking in Bangladesh and India and hazardous industries located throughout the periphery have taken a wide variety of forms: various national and regional regulatory efforts such as the 2013 European Union (EU) Shipbreaking Regulation banning EU flagged ships from being beached in Asia; bilateral and multilateral environmental agreements; various international conventions, including the Basel Convention on the Control of Transboundary Movements of Hazardous Wastes and Their Disposal (hereafter the Basel Convention) and the Hong Kong International Convention for the Safe and Environmentally Sound Recycling of Ships (Hong Kong International Convention) adopted in May 2009 under the auspices of the International Maritime Organization, that becomes effective in 2015 (see Bhattacharjee 2009; European Commission DG Environment 2009; Frey 2006a; Karim 2010; Lucier and Gareau 2014; Moen 2008; Okereke 2008:80-98; Puthucherril 2010, 2011); Codes of Conduct such as the International Chamber of Shipping Industry Code of Practice on Ship Recycling; and a range of trade treaties (see, e.g., Demaria 2010; Greenpeace International and International Federation for Human Rights 2005; Hossain and Islam 2006; International Federation for Human Rights 2002; Okereke 2008; Puthucherril 2010: Chapters 3-5, 2011; Rousmaniere and Raj 2007; World Bank 2010). These efforts to "globalize responsibility" are problematic because of noncompliance and weak implementation and enforcement capacity at the national and supranational levels, resulting from fragmented efforts, limited resources, increased capital mobility, the neoliberal project that frames regulation as a trade barrier, and increasing legitimation discourse efforts by exporting countries and

\footnotetext{
${ }^{14}$ Or, as Herman Daly (1993:57) has noted: "By separating the costs and benefits of environmental exploitation, international trade makes them harder to compare." To put it another way, the "metabolic rift" between the core and (semi) periphery (Foster, Clark, and York 2010; see also Moore 2000, 2011a) resulting from ecological unequal exchange is made invisible by globalization and the attendant market ideology espoused by proponents of the neoliberal perspective and ecological modernization.
} 
industry lobbies to redefine hazardous wastes as "resources" to be recycled (see, e.g., Bhattacharjee 2009; Frey 1998a, 2006a, 2006b; Greenpeace International and International Federation for Human Rights 2005; Karim 2010; Lucier and Gareau 2014). ${ }^{15}$

Several analysts have called for more stringent measures, including "the renationalization of capital" (Daly 1996:145-162) or the dismantling of what Schnaiberg (1980) and his colleagues (Gould et al.1996, 2008) have called the "transnational treadmill of production." Implementation of such proposals appears unlikely given the structural constraints posed by the current world-system. In effect, stopping the displacement of hazards or environmental harms (as noted elsewhere [Frey 2006a]) through the "globalization of responsibility" or the "renationalization of capital" is unlikely as long as the core countries control a majority of the wealth generated in the world-system.

What is actually being done to challenge ship breaking as it is currently practiced in Bangladesh and India? Several organizational and political activities are currently underway. Non-governmental organizations (NGOs, including Bangladesh Environmental Lawyers Association, Toxic Links, Human Rights Law Network, and Young Power in Social Action) have pressured state authorities in Bangladesh and India to develop and enforce higher standards and open the policy discourse to the public about toxic wastes (Demaria 2010; Rousmaniere and Raj 2007). Several labor organizations (e.g., Alang-Sosyia Recycling and General Workers' Association) have sponsored strikes for better wages and working conditions with limited success. International NGOs such as Greenpeace International, the Basel Action Network (BAN), and Platform on Shipbreaking monitor and study actual conditions in and around the yards, as well as pressure yard owners and state authorities to change operating procedures (see, e.g., Demaria 2010; Greenpeace International 2000, 2001; Greenpeace International and International Federation for Human Rights 2005; Rousmaniere and Raj 2007). Greenpeace International, the Basel Action Network, the Ship Breaking Platform, and other organizations (such as the International Maritime Organization, the International Labour Organization, International Metalworkers Federation, the European Commission Director General of the Environment, and the United Nations Environment Programme) as well as many analysts have made a number of specific recommendations (European Commission Director General of the Environment 2009; International Federation for Human Rights 2002; Greenpeace International and International Federation for Human Rights 2005; Hossain and Islam 2006; Puthucherril 2010, 2011:191-207; Aahu 2014). These include:

- Ship breaking yards should be open to inspection by NGOs, trade unions, and other groups.

- Operating ships should be made cleaner through maintenance and retrofitting.

- A global regulatory regime should be developed and fully implemented to regulate ship breaking.

- The next generation of ships should be constructed to reduce health, safety, and

\footnotetext{
${ }^{15}$ The 2013 European Union Shipbreaking Regulation banning ship beaching in Asia is easily defied by changing nation of registry (Kotoky 2015). See Lucier and Gareau (2014) for a discussion of efforts by interested economic actors to redefine how hazardous wastes should be regulated under the Basel Convention. They provide an insightful discussion of efforts by exporting countries and industry lobby groups to redefine hazardous wastes as "resources" to be recycled in an effort to marginalize environmental injustice claims and to therefore define "appropriate policy" and promote their economic interests. See also Puthucherril's $(2010,2011)$ detailed and critical discussion of the ambitious Hong Kong International Convention and other efforts to curb the risks associated with ship breaking. See also Karim's (2010) excellent discussion.
} 
environmental impacts at the time of decommissioning.

- Ship owners and flag state holders should be responsible for the clean and safe dismantling of ships.

- Workers should be protected through improved health and safety practices in the yards.

Economic globalization and the attendant adverse consequences have clearly fostered counter-hegemonic forces or anti-systemic movements (see, e.g., Arrighi et al. 2012; Bandy and Smith 2005; Keck and Sikkink 1998; Martinez-Alier 2002; Pellow 2007, 2011; Smith and Wiest 2012; Wallerstein 2002) in the form of transnational networks of NGOs. The extent to which national and transnational NGOs will actually curb the adverse consequences of economic globalization in India, Bangladesh, and elsewhere is the subject of much debate (see, e.g., Brecher et al. 2000, Buraway, 2010; Chase-Dunn 2002, 2010; Evans 2000; Mol 2001; Pellow 2007: Chapters 3 and 7, 2011; Swerts 2013; Wallerstein 2002). Counter-hegemonic globalization in the form of transnational networks of NGOs (referred to as "globalization from below" by Brecher et al. [2000] and Chase-Dunn [2002, 2010], among others) is often seen as a viable means for curbing some of the worst abuses associated with the transfer of hazardous production processes, whether ship breaking, e-waste recycling, battery recycling, or otherwise, to "sacrifice zones" located in the (semi) periphery (see also Frey 2012a; Gould et al. 2008:103-104; Pellow 2007; Smith and Wiest 2012). This approach is not without its critics, who argue that domestic NGOs involved in transnational networks often become dependent on Western financial resources and frames and exclude those directly engaged in or affected by ship breaking and other forms of hazardous production practices from the political process, contributing to what Swerts (2011) calls a "democracy deficit." Transnational networks of NGOs seem incapable of providing the strong opposition needed to curb the adverse consequences of the industry.

Stopping ship breaking - in other words ending the core's appropriation of the periphery's carrying capacity or "environmental space"-is difficult, for it is deeply embedded in the very structure of the current world-system and influences the domestic political economy of both Bangladesh and India. Ship breakers/yard owners lobby hard against state regulation and judicial activism (Demaria 2010; Parman 2012) with considerable success. ${ }^{16}$ This latter point is well illustrated by state efforts of both countries to curb anti-ship breaking NGO activity and strong regulation by branding such policies as anti-developmental and disruptive to business activity (Bahree 2014). And there are few financial incentives (in this "race to the bottom") for Bangladesh and India who are in direct competition with each other and the other ship breaking countries (China, Pakistan, and Vietnam) to establish strong regulatory measures comparable to those found in Europe, Japan, South Korea, and North America or to stop breaking ships. In sum, the ecological unequal relations these two countries share with the core are important for maintaining elite advantage in Bangladesh and India and continuous capital accumulation in the core as noted above. ${ }^{17}$

\footnotetext{
${ }^{16}$ See Demaria's (2010:256-259) discussion of the Indian Supreme Court and the "Blue Lady" case and the Bangladeshi Supreme Court's 2010 restrictions on ship breaking in Chittagong (Anonymous, 2011). See also Karim (2010) for additional discussion of the issue.

${ }^{17}$ Puthucherril (2010:12) is much more optimistic. He notes “... international standards for ship recycling, along with greater North-South cooperation, are necessary to ensure sustainable ship recycling."
} 


\section{Conclusion}

What this paper brings into sharp focus is the ecological contradictions of globalization and the current world-system. To be more specific, it contributes to the emerging literature on ecological unequal exchange and what some have called the exploitation of environmental space by the advanced capitalist center. Much of the existing literature has focused on the extraction of wealth from the "resource frontiers" located in the peripheral zones of the world-system. The ship breaking case reported here represents an important example of the displacement of the core's anti-wealth to the "waste disposal frontiers" of the (semi) periphery and the resulting adverse health, safety, environmental, and socio-economic consequences for the periphery. Ship breaking illustrates quite clearly that capital accumulation in the core is dependent on (semi) peripheral contamination.

Much more research is needed on core capital accumulation through (semi) peripheral contamination and the process of ecological unequal exchange. Future research should look at the full range of hazardous production practices and wastes that are displaced to the "waste disposal frontiers" and the resulting political conflicts and responses. One direction for future research should be the examination of the movement of the core's hazardous production practices to the more than 3,500 export processing zones located in (semi) peripheral countries scattered throughout Asia, Africa, Latin America, and the Caribbean (Dicken 2011:193, 2015). These zones have limited regulatory restrictions on hazardous production practices and waste disposal and offer many other concessions to core capital that facilitate capital accumulation, including harsh restrictions on domestic and transnational NGO activity. The zones represent an increasingly important feature of the expanding rift in the world-system (resulting from ecological unequal exchange) and needs to be more fully addressed in efforts to understand relations between the core and (semi) peripheral zones in the world-system.

\section{References}

Adams, Richard N. 1988. The Eighth Day: Social Evolution as the Self-Organization of Energy. Austin: University of Texas Press.

Alario, Margarita V. and William R. Freudenburg. 2010. "Titanic Risks Are Not So Titanic After All." Sociological Inquiry 80: 500-512.

American Association of Port Authorities. 2008. "World Port Rankings 2008." Available at www.aapa-ports.org/Industry/.

Anonymous. 2008. "Alang Loses Out to Bangladesh." Seatrade Asia Online (August 28). . 2011. "Scrap Ship Import Gets Further Extension." The Daily Star (Online Report July 21).

Arrighi, Giovanni, Terrence Hopkins, and Immanuel Wallerstein. 2012. Anti-Systemic Movements. London: Verso.

Auyero, Javier and Debora Alejandra Swistun. 2009. Flammable: Environmental Suffering in an Argentine Shantytown. New York: Oxford University Press.

Bahree, Megha. 2014. "Modi Government's Message to NGOs in India: Big Brother is Watching 
You." Forbes (June 16) Available at http://www.forbes.com.

Bandy, Joe and Jackie Smith, editors. 2005. Coalitions across Borders: Transnational Protest and the Neoliberal Order. Lanham, MD: Rowman and Littlefield.

Basha, Shaik, Premsingh Mansingh Gaur, Ravikumar Bhagwan Thorat, Rohitkumar Harikrishna Trivedi, Sandip Kumar Mukhopadhyay, Nisha Anand, Shalin Hemantbhai Desai, Kalpana Haresh Mody, and Bhavnath Jha. 2007. "Heavy Metal Content of Suspended Particulate Matter at World's Largest Ship-Breaking Yard, Alang-Sosiya, India." Water, Air, and Soil Pollution 178: 373-384.

Beck, Ulrich. 1992. Risk Society: Towards a New Modernity. London: Sage. . 1999. World Risk Society. Malden, MA: Blackwell.

Bhattacharjee, Saurabh. 2009. "From Basel to Hong Kong: International Environmental Regulation of Ship-Recycling Takes One Step Forward and Two Steps Back." Trade, Law and Development 1: 193-230.

Bonds, Eric and Liam Downey. 2012. "'Green Technology' and Ecological Unequal Exchange: The Environemntal and Social Consequences of Ecological Modernization in the WorldSystem." Journal of World-Systems Research 18: 167-186.

Brecher, Jeremy, Tim Costello, and Brendan Smith. 2000. Globalization from Below: The Power of Solidarity. Cambridge, MA: South End Press.

Buerk, Roland. 2006. Breaking Ships: How Supertankers and Cargo Ships Are Dismantled on the Shores of Bangladesh. New York: Chamberlain Brothers.

Bullard, Robert D., Glenn S. Johnson, and Angel O. Torres. 2005. "Addressing Global Poverty, Pollution, and Human Rights." Pp. 279-297 in The Quest for Environmental Justice: Human Rights and the Politics of Pollution, edited by Robert D. Bullard. San Francisco: Sierra Books.

Bunker, Stephen G. 1985. Underdeveloping the Amazon: Extraction, Unequal Exchange, and the Failure of the Modern State. Urbana: University of Illinois Press. . 2007. "Natural Values and the Physical Inevitability of Uneven Development under Capitalism." Pp. 239-258 in in Rethinking Environmental History: World-System History and Global Environmental Change, edited by Alf Hornborg, J.R. MeNeill, and Joan Martinez-Alier. New York: AltaMira Press.

Bunker, Stephen G. and Paul S. Ciccantell. 2005. Globalization and the Race for Resources. Baltimore, MD: The Johns Hopkins University Press.

Buraway, Michael. 2010. "From Pollyanna: The False Optimism of Global Labor Studies." Global Labour Journal 1: 301-313.

Carmin, Jo Ann and Julian Agyeman, editors. 2011. Environmental Inequalities Beyond Borders: Local Perspectives on Global Injustices. Cambridge, MA: The MIT Press.

Chase-Dunn, Christopher. 2002. "Globalization from Below: Toward a Collectively Rational and Democratic Commonwealth." Annals of the American Academy of Political and Social Sciences 581:48-61. . 2010. "Globalization from Below: Toward a Democratic Global Commonwealth." Journal of Globalization Studies 1: 46-57.

Clapp. Jennifer. 2001. Toxic Exports: The Transfer of Hazardous Wastes from Rich to Poor Countries. Ithaca, NY: Cornell University Press. . 2002. "What the Pollution Haven Debate Overlooks." Global Environmental Politics 2: 11-19.

Clark, Brett and John Bellamy Foster. 2009. "Ecological Imperialism and the Global Metabolic 
Rift: Unequal Exchange and the Guano/Nitrates Trade." International Journal of Comparative Sociology 50: 311-334.

Clelland, Donald A. 2014. "The Core of Apple: Dark Value and Degrees of Monopoly in Global Commodity Chains." Journal of World-Systems Research 20: 82-111.

Cole, Matthew A. 2004.'Trade, the Pollution Haven Hypothesis and the Environmental Kuznets Curve: Examining the Linkages." Ecological Economics 48: 71-81.

Commission for Environmental Cooperation. 2012. Hazardous Trade? An Examination of US Generated Lead-Acid Battery Exports and Secondary Lead Recycling in Mexico, the United States, and Canada. Montreal, Canada: Commission for Environmental Cooperation. Located at http://www.cec.org/Storage/142/16758 SLAB-publicdraft30 Nov en.pdf

Cudahy, Brian. 2006. Box Boats: How Container Ships Changed the World. New York: Fordham University Press.

Daly, Herman. 1993. "The Perils of Free Trade." Scientific American 262: 50-57. . 1996. Beyond Growth: The Economics of Sustainable Development. Boston: Beacon Press.

Demaria, Federico. 2010. "Shipbreaking at Alang-Sosiya (India): An Ecological Distribution Conflict." Ecological Economics 70: 250-260.

Dick, Christopher and Andrew K. Jorgenson. 2011. "Capital Movements and Environmental Harms." Journal of World-Systems Research 37: 482-497.

Dicken, Peter. 2011. Global Shift: Mapping the Contours of the World Economy. (Sixth Edition.) New York: Guilford Press.

. 2015. Global Shift: Mapping the Contours of the World Economy. (Seventh Edition.) New York: Guilford Press.

Dietz, Thomas and Eugene A. Rosa. 1997. "Effects of Population and Affluence on CO2 Emissions." Proceedings of the National Academy of Sciences of the USA 94: 175-179.

Dietz, Thomas, R. Scott Frey, and Eugene Rosa. 2002. "Technology, Risk, and Society." Pp. 329-369 in Handbook of Environmental Sociology, edited by Riley Dunlap and William Michelson. Westport, CT: Greenwood Press.

The Editors. 2007. Editorial. The Economist (June 9): 14.

Ehrlich, Paul R. and John P. Holdren. 1971. "Impact of Population Growth." Science 171: 12121217.

Eskeland, Gunnar S. and Ann E. Harrison. 2003. "Moving to Greener Pastures?: Multinationals and the Pollution Haven Hypothesis." Journal of Development Economics 70: 1-23.

European Commission DG Environment. 2009. Support to the Impact Assessment of a New Legislative Proposal on Ship Dismantling. Kongens Lyngby, Denmark: COWI.

Evans, Peter. 2000. "Fighting Marginalization with Transnational Networks: Counter Hegemonic Globalization." Contemporary Sociology 29: 230-241.

Faber, Daniel. 2008. Capitalizing on Environmental Injustice: The Polluter-Industrial Complex in the Age of Globalization. Lanham, MD: Rowman and Littlefield. . 2009. "The Unfair Trade-off: Globalization and the Export of Ecological Hazards." Pp. 181-199 in Environmental Sociology: From Analysis to Action, edited by Leslie King and Deborah McCarty. Lanham, MD: Rowman and Littlefield.

Foster, John Bellamy. 2002a. "The Ecological Tyranny of the Bottom Line: The Environmental and Social Consequences of Economic Reductionism." Pp. 26-43 in Ecology Against Capitalism, by John Bellamy Foster. New York: Monthly Review Press. 
. 2002b. "Let Them Eat Pollution: Capitalism in the World Environment." Pp. 6068 in Ecology Against Capitalism, by John Bellamy Foster. New York: Monthly Review Press.

Foster, John Bellamy, Brett Clark, and Richard York. 2010. The Ecological Rift: Capitalism's War on the Earth. New York: Monthly Review Press.

Foster, John Bellamy and Hannah Holleman. 2014. "The Theory of Unequal Ecological Exchange: A Marx-Odum Dialectic." The Journal of Peasant Studies 41: 199-233.

Freudenburg, William R. and Robert Gramling. 2011. Blowout in the Gulf: The BP Oilspill Disaster and the Future of Energy in America. Cambridge, MA: The MIT Press.

Frey, R. Scott. 1995. "The International Traffic in Pesticides." Technological Forecasting and Social Change 50: 151-169.

. 1998a. "The Hazardous Waste Stream in the World-System." Pp. 84-103 in Space and Transport in the World-System, edited by Paul Ciccantell and Stephen G. Bunker. Westport, CT: Greenwood Press.

1998b. "The Export of Hazardous Industries to the Peripheral Zones of the WorldSystem." Journal of Developing Societies 14: 66-81.

. 2006a "The Flow of Hazardous Exports in the World-System." Pp. 133-149 in Globalization and the Environment, edited by Andrew Jorgenson and Edward Kick. Leiden, The Netherlands and Boston: Brill Academic Press.

. 2006b. "The International Traffic in Asbestos." Nature, Society, and Thought 19: 173 180.

. 2012a. "The E-Waste Stream in the World-System." Journal of Globalization Studies 3: 79-94.

. 2012b. "The Displacement of Hazardous Products, Production Processes, and Wastes in the World-System." Pp. 440-442. Handbook of World-Systems Analysis: Theory and Research, edited by Salvatore Babones and Christopher Chase-Dunn. New York: Routledge. . 2013. "Cigarette Trafficking in the World-System." Journal of Globalization Studies 4: 74-81.

Frey, R. Scott, Sabrina McCormick, and Eugene A. Rosa. 2007. "The Sociology of Risk." Pp. 81-87 in The Handbook of $21^{\text {st }}$ Century Sociology, Volume II, edited by Clifton D. Bryant and Dennis Peck. Thousand Oaks, CA: Sage.

Funtowicz, Silvio O. and Jerome R. Ravetz. 1994. "The Worth of a Songbird: Ecological Economics as a Post-Normal Science." Ecological Economics 10: 197-207.

Gottesfeld, Perry and Amod K. Pokhrel. 2011. "Review: Lead Exposure to Battery Manufacturing and Recycling in Developing Countries and Among Children in Nearby Communities." Journal of Occupational and Environmental Hygiene 8: 520-532.

Gould, Kenneth A., David N. Pellow, and Allan Schnaiberg. 2008. The Treadmill of Production: Injustice and Unsustainability in the Global Economy. Boulder, CO: Paradigm Publishers.

Gould, Kenneth A., Allan Schnaiberg, and Adam S. Weinberg. 1996. Local Environmental Struggles: Citizen Activism in the Treadmill of Production. New York: Cambridge University Press.

Greenpeace International. 2000. Shipbreaking: A Global Environmental, Health, and Labour Challenge. Amsterdam, The Netherlands: Greenpeace International. . 2001. Steel and Toxic Wastes for Asia: Findings of a Greenpeace Study on Workplace 
and Environmental Contamination in Alang-Sosiya Shipbreaking Yards, Gujarat, India. Amsterdam, The Netherlands: Greenpeace International.

Greenpeace International and International Federation for Human Rights. 2005. End of Life Ships: The Human Cost of Breaking Ships. Amsterdam, The Netherlands: Greenpeace International.

Grineski, Sara E., Timothy W. Collins, Maria de Loures Romo Aguilar, and Raed Aldouri. 2010. 'No Safe Place: Environmental Hazards and Injustice along Mexico's Northern Border." Social Forces 88: 2241-2266.

Grossman, Gene M. and Alan B. Krueger. 1993. "Environmental Impacts of a North America Free Trade Agreement." In The Mexico-U.S. Free Trade Agreement, edited by Peter M. Garber. Cambridge, MA: The MIT Press.

. 1995. "Economic Growth and the Environment." The Quarterly Journal of Economics 110: 350-377.

Halpern, Benjamin S., Shaun Walbridge, Kimberly A. Selkoe, Carrie V. Kappel, Fiorenza Micheli, Caterina D'Agrosa, John F. Bruno, Kenneth S. Casey, Colin Ebert, Helen E. Fox, Rod Fujita, Dennis Heinemann, Hunter S. Leniham, Elizabeth M.P. Madin, Matthew T. Perry, Elizabeth R. Selig, Mark Spalding, Robert Steneck, and Reg Watson. 2008. "A Global Map of Human Impact on Marine Ecosystems." Science 319 (15 February): 948-952.

Harvey, David. 1996. Justice, Nature and the Geography of Difference. Malden, MA: Blackwell. . 2010. The Enigma of Capital and the Crises of Capitalism. New York: Oxford University Press.

Hooks, Gregory and Chad L. Smith. 2012. "The Treadmill of Destruction Goes Global: Anticipating the Environmental Impact of Militarism in the $21^{\text {st }}$ Century." Pp. 60-83 in Stratocracy: Society and the Marketing of War in the Age of Neo-Militarism, edited by Kostas Gouliamos and Christos Kassimeris.

Hornborg, Alf. 1998. "Towards an Ecological Theory of Unequal Exchange: Articulating World System Theory and Ecological Economics." Ecological Economics 25: 127-136.

. 2009. "Zero-Sum Game: Challenges in Conceptualizing Environmental Load Displacement and Ecologically Unequal Exchange." International Journal of Comparative Sociology 50: 237-262.

. 2011. Global Ecology and Unequal Exchange: Fetishism in a Zero-Sum World. New York: Routledge.

Hossain, M. Maruf and Mohamamad Mahmudul Islam. 2006. Ship Breaking Activities and Its Impact on the Coastal Zone of Chittagong, Bangladesh: Towards Sustainable Development. Chittagong, Bangladesh: Young Power in Social Action.

International Federation for Human Rights. 2002. Where Do the 'Floating Dustbins' End Up? Paris: International Federation for Human Rights.

International Federation for Human Rights and Young Power in Social Action. 2008. Child Breaking Yards: Child Labour in the Ship Recycling Industry in Bangladesh. Paris: International Federation for Human Rights.

International Maritime Association. 2011. International Shipping Facts and Figures Information Resources on Trade, Safety, Security, and the Environment. London: International Maritime Association.

Jorgenson, Andrew K. 2006. "Global Warming and the Neglected Greenhouse Gas: A Cross- 
National Study of the Social Causes of Methane Emissions Intensity, 1995." Social Forces 84: 1779-1799.

Jorgenson, Andrew and Brett Clark, editors. 2009a. "Ecologically Unequal Exchange in Comparative Perspective." Theme Issue, International Journal of Comparative Sociology $50(3-4)$.

. 2009b. "The Economy, Military, and Ecologically Unequal Relationships in Comparative Perspective: A Panel Study of the Ecological Footprints of Nations, 19752000." Social Problems 56: 621-646.

Karim, Md. Saiful. 2010. "Environmental Pollution from Shipbreaking Industry: International Law and National Legal Response." Georgetown International Environmental Law Review 22: 185-240.

Keck, Margaret and Kathryn Sikkink. 1998. Activists Beyond Borders. Ithaca, NY: Cornell University Press.

Kentor, Jeffrey and Peter Grimes. 2006. "Foreign Investment Dependence and the Environment: A Global Perspective." Pp. 61-77 in Globalization and the Environment, edited by Andrew Jorgenson and Edward Kick. Leiden, The Netherlands and Boston: Brill Academic Press.

Kotoky, Aurang. 2015. "Changing Flags to Use India's Ship Graveyard." Bloomberg News (February 12) at www.bloomberg.com/news/articles.

Langewiesche, William. 2004. The Outlaw Sea: Chaos and Crime on the World's Oceans. New York: North Point Press.

Lerner, Steve. 2010. Sacrifice Zones: The Front Lines of Toxic Chemical Exposure in the United States. Cambridge, MA: MT Press.

Levinson, Arik and M. Scott Taylor. 2008. "Unmasking the Pollution Haven Effect." International Economic Review 49: 223-254.

Levinson, Marc. 2006. The Box: How the Shipping Container Made the World Smaller and the World Economy Bigger. Princeton: Princeton University Press.

Logan, Bernard I. 1991. "An Assessment of the Environmental and Economic Implications of Toxic-Waste Disposal in Sub-Saharan Africa." Journal of World Trade 25: 61-76.

Lucier, Cristina A. and Brian J. Gureau. 2014. "Obstacles to Preserving Precaution and Equity in Global Hazardous Waste Regulation: An Analysis of Contested Knowledge in the Basel Convention." International Environmental Agreements (Published online in September, DOI 10.1007/s10784-014-926-6)

Margai, Florence and Fatoumata B. Barry. 2011. "Global Geographies of Environmental Injustice and Health: A Case Study of Illegal Hazardous Waste Dumping in Côte d'Ivoire." Pp. 257-281 in Julianna A. Maantay and Sara McLafferty, editors. Geospatial Analysis of Environmental Health. New York: Springer.

Martinez-Alier, Joan. 2002. The Environmentalism of the Poor: A Study of Ecological Conflicts and Valuation. Cheltenham, UK: Edward Elgar.

. 2007. "Marxism, Social Metabolism, and International Trade." Pp. 221-237 in Rethinking Environmental History: World-System History and Global Environmental Change, edited by Alf Hornborg, J.R. McNeill, and Joan Martinez-Alier. New York: AltaMira Press. . 2009. "Social Metabolism, Ecological Distribution Conflicts, and Languages of Valuation." Capitalism Nature Socialism 20: 58-87.

Mitchell, Robert Cameron and Richard T. Carson. 1989. Using Surveys to Value Public Goods: The Contingent Valuation Method. Washington, D.C.: Resources for the Future. 
Moen, Amy. 2008. "Breaking Basel: The Elements of the Basel Convention and its Application to Toxic Ships." Marine Policy 32: 1053-1062.

Mol, Arthur P. 2001. Globalization and Environmental Reform: The Ecological Modernization of the Global Economy. Cambridge, MA: The MIT Press.

Moore, Jason W. 2000. "Environmental Crises and the Metabolic Rift in World-Historical Perspective." Organization and Environment 13: 123-157. . 2007. "Silver, Ecology, and the Origins of the Modern World, 1450-1640." Pp. 123-142 in Rethinking Environmental History: World-System History and Global Environmental Change, edited by Alf Hornborg, J.R. McNeill, and Joan Martinez-Alier. New York: AltaMira Press.

.2010a. "'Amsterdam is Standing on Norway' Part I: The Alchemy of Capital, Empire and Nature in the Diaspora of Silver, 1545-1648." Journal of Agrarian Change 10:33-68. . 2010b. "Amsterdam is Standing on Norway' Part II: The Global North Atlantic in the Ecological Revolution of the Long Seventeenth Century." Journal of Agrarian Change 10: $188-227$.

.2011a. "Transcending the Metabolic Rift: A Theory of Crises in the Capitalist WorldEcology." The Journal of Peasant Studies 38: 1-46.

. 2011b. "Ecology, Capital, and the Nature of Our Times: Accumulation \& Crisis in the Capitalist World-Ecology." Journal of World Systems Research 42:107-146.

Muradian, Roldan and Stefan Giljum. 2007. "Physical Trade Flows of Pollution-Intensive Products: Historical Trends in Europe and the World." Pp. 307-325 in Rethinking Environmental History: World-System History and Global Environmental Change, edited by Alf Hornborg, J.R. McNeill, and Joan Martinez-Alier. New York: AltaMira Press.

Nixon, Rob. 2011. Slow Violence and the Environmentalism of the Poor. Cambridge, MA: Harvard University Press.

Okereke, Chukwumerije. 2008. Global Justice and Neoliberal Environmental Governance: Ethics, Sustainable Development and International Cooperation. London and New York: Routledge.

Parmar, Vijaysinh. 2012. "Strike in Alang to Protest Arrests of Ship Breakers." The Times of India (October, 12). Available at www.timesofindia.com.

Pellow, David Naguib. 2007. Resisting Global Toxics: Transnational Movements for Environmental Justice. Cambridge, MA: The MIT Press.

. 2011. "Politics by Other Greens: The Importance of Transnational Environmental Justice Movement Networks." Pp. 247-266 in Environmental Inequalities Beyond Borders: Local Perspectives on Global Injustices, edited by Jo Ann Carmin and Julian Agyeman. Cambridge, MA: The MIT Press.

Prew, Paul. 2010. "World-Economy Centrality and Carbon Dioxide Emissions; A New Look at Position in the Capitalist World-System and Environmental Pollution." Journal of World-Systems Research 16: 162-191.

Price-Smith, Andrew T. 2001. The Health of Nations: Infectious Diseases, Environmental Change and the Effects of National Security and Development. Cambridge, MA: MIT Press.

Puthucherril, Tony George. 2010. From Shipbreaking to Sustaianable Ship Recycling: Evolution of a Legal Regime. Leiden and Boston: Martinus Nijhoff. 
. 2011. "Trans-boundary Movement of Hazardous Ships for their Last Rites: Will the Ship Recycling Conventions Make a Difference." Ocean Yearbook 24: 283-330.

Reddy, M. Srinivasa, Shaik Basha, H.V. Joshi, and G. Ramachandraiah. 2005. "Seasonal Distribution and Conatmination Levels of Total PHCs, PAHs and Heavy Metals in Coastal Waters of the Alang-Sosiya Ship Scrapping Yard, Gulf of Cambay, India." Chemosphere 61: 1587-1593.

Rice, James. 2007. "Ecological Unequal Exchange: International Trade and Uneven Utilization of Environmental Space in the World System." Social Forces 85: 1369-1392.

. 2009. "The Transnational Organization of Production and Uneven Environmental Degradation and Change in the World Economy." Journal of Comparative International Sociology 50: 215-236.

. 2011. "The Global Reorganization and Revitalization of the Asbestos Industry, 19702007." International Journal of Health Sciences 41: 239-254.

Rifkin, Jeremy. 1980. Entropy: A New World View. New York: The Viking Press.

Roberts, J. Timmons, Peter Grimes, and Jodie Manale. 2006. "Social Roots of Global Environmental Change: A World-Systems Analyis of Carbon Dioxide Emissions." Pp. 79-117 in Globalization and the Environment, edited by Andrew Jorgenson and Edward Kick. Leiden, The Netherlands and Boston: Brill Academic Press.

Roberts, J. Timmons and Bradley C. Parks. 2007. A Climate of Injustice: Global Inequality, North-South Politics, and Climate Policy. Cambridge, MA: The MIT Press

Robindebois.org. 2008. Special issue. Global statement 2008 of ships sent to demolition. Available at www.robindesbois.org. 2009. Special issue. Global statement of 2007 ships sent to demolition. Available at www.robindesbois.org. 2010. 2009 Collection. Shipbreaking.com \#15 to 18-Ships sent to demolition from January $1^{\text {st }}$ to decembre $31^{\text {st }}$. Available at www.robindesbois.org. .2011. 2010 Collection. Shipbreaking.com \#19 to 22 - Ships sent to demolition from January 1 to decembre $31^{\text {st }}$. Available at www.robindesbois.org.

Robins, Nicholas A. 2011. Mercury, Mining, and Empire: The Human and Ecological Cost of Colonial Silver Mining in the Andes. Bloomington and Indianapolis: Indiana University Press.

Rousmaniere, Peter and Nikhil Raj. 2007. "Shipbreaking in the Developing World: Problems and Prospects." International Journal of Occupational and Environmental Health 13: 359368.

Sahu, Geetanjoy. 2014. "Workers of Alang-Sosiya: A Survey of Working Conditions in a ShipBreaking Yard, 1983-2013." Economic and Political Weekly 49: 52-59.

Schnaiberg, Allan. 1980. Environment: From Surplus to Scarcity. New York: Oxford University Press.

Shin, Kyoung-ho and Paul S. Ciccantell. 2009 "The Steel and Shipbuilding Industries of South Korea: Rising East Asia and Globalization." Journal of World Systems Research 15: 167192.

Smith, Jackie and Dawn Wiest. 2012. Social Movements in the World-System: The Politics of Crisis and Transformation. New York: Russell Sage Foundation.

Subramaniam, Mangala. 2015. "Introduction: States and Social Movements in the Modern World-System." Journal of World System Research.

Summers, Lawrence. 1991. Selections from a World Bank Memo. The Economist 
(February 8): 66.

Swerts, Thomas. 2013. "The Democratic Deficit of Transnational Environmental Activism: A Case Study of E-Waste Governance in India." Global Networks 13: 498-516.

Tewari, A., H. V. Joshi, R. H. Trivedi, V. G. Sravankumar, C. Raghunathan, Y. Khambhaty, O. S. Kotiwar, and S. K. Mandal. 2001. "The Effect of Ship Scrapping Industry and Its Associated Wastes on the Biomas Production and Biodiversity of Biota in in situ Condition at Alang." Marine Pollution Bulletin 42: 462-469.

Uglietti, Chiara, Colin A. Cook, Paul Vallelonga, and Lonne G. Thompson. 2015. "Widespread Pollution of the South American Atmosphere Predates the Industrial Revolution by 240 Y." National Academies of Science 112:2349-2354.

Urry, John. 2014. Offshoring. Cambridge, MA: Polity.

Wallerstein, Immanuel. 1974-2011. The Modern World System. (4 Volumes.) New York: Academic Press. 2000. The Essential Wallerstein. New York: The New Press. . 2002. "New Revolts Against the System." New Left Review 18 (November-December): 29-39. . 2004. World-Systems Analysis: An Introduction. Durham, NC: Duke University.

World Bank. 2010. Ship Breaking and Recycling Industry in Bangladesh and Pakistan. Washington, D.C.: World Bank.

Wu, Wei-Te, Yu-Jen Lin, Huei-Sheng Shiue, Chung-Yi Li, Perng-Jy Tsai, Chun-Yuh Yang, Saou-Hsing Liou, and Trong-Neng Wu. 2014. "Cancer Incidence of Taiwanese Shipbreaking Workers Who Have Been Potentially Exposed to Asbestos." Environmental Research 132: 370-378.

York, Richard and Eugene A. Rosa. 2003. "Key Challenges to Ecological Modernization Theory." Organization and Environment 16: 273-288.

York, Richard, Eugene A. Rosa, and Thomas Dietz. 2003. "A Rift in Modernity? Assessing the Anthropogenic Sources of Global Climate Change with the STIRPAT Model." International Journal of Sociology and Social Policy 23: 31-51.

York, Richard and Eugene A. Rosa. 2006. "Emissions of Sulpher Dioxide and Nitrogen Oxides." Pp. 119-132 in Globalization and the Environment, edited by Andrew Jorgenson and Edward Kick. Leiden, The Netherlands and Boston: Brill Academic Press. 